\title{
The oldest known record of a ground sloth (Mammalia, Xenarthra, Folivora) from Hispaniola: evolutionary and paleobiogeographical implications
}

\author{
Lazaro W. Viñola-Lopez, ${ }^{1,2 *}$ (D) Elson E. Core Suárez, ${ }^{3}$ Jorge Vélez-Juarbe, ${ }^{4,5}$ (b) Juan N. Almonte Milan, ${ }^{6}$ \\ and Jonathan I. Bloch ${ }^{1}$ \\ ${ }^{1}$ Florida Museum of Natural History, University of Florida, P.O. Box 117800, Gainesville, FL 32611, USA <lwv194@ gmail.com>, \\ <jbloch@flmnh.ufl.edu> \\ ${ }^{2}$ Department of Biology, University of Florida, Gainesville, FL 32611, USA \\ ${ }^{3}$ Department of Geology, University of Kansas, 1475 Jayhawk Blvd., Lawrence, KS 66045, USA <core@ku.edu> \\ ${ }^{4}$ Department of Mammalogy, Natural History Museum of Los Angeles County, 900 Exposition Blvd., Los Angeles, CA 90007, USA \\ $<$ velezjuarbe@gmail.com> \\ ${ }^{5}$ Department of Paleobiology, National Museum of Natural History, Smithsonian Institution, Washington, DC 20560, USA \\ ${ }^{6}$ Museo Nacional de Historia Natural “Prof. Eugenio de Jesús Marcano”, Santo Domingo, Dominican Republic j.almonte@mnhn.gov.do
}

\begin{abstract}
Sloths were among the most diverse groups of land vertebrates that inhabited the Greater Antilles until their extinction in the middle-late Holocene following the arrival of humans to the islands. Although the fossil record of the group is well known from Quaternary deposits in Cuba, Hispaniola, and Puerto Rico, remains from older units are scarce, limiting our understanding of their evolution and biogeographic history. Here we report the oldest known fossil ground sloth from Hispaniola, represented by an unassociated partial tibia and scapula that are recognized as a single taxon from the late Miocene-early Pliocene of the Dominican Republic. The combination of characters observed on the tibia suggests a close relationship with Megalocnus, otherwise only known from the Pleistocene-Holocene of Cuba. These fossils fill a temporal gap between those previously known from the early Miocene of Cuba and those from Pleistocene-Holocene deposits in the region and provide additional support for a continuous presence of the group in the Greater Antilles since the Oligocene.
\end{abstract}

\section{Introduction}

Extant sloths are represented by only two arboreal genera, Bradypus Linnaeus, 1758, and Choloepus Illiger, 1811, found in the tropical forest of Central and South America. Although absent from the Greater Antilles today, the region was inhabited by an impressive diversity of megalocnid sloths (Silva-Taboada et al., 2007) — an endemic clade thought to be sister to all other living and extinct continental members of Folivora, according to recent molecular analyses (Delsuc et al., 2019; Presslee et al., 2019). These molecular analyses further suggest that the ancestors of megalocnid sloths arrived in the Caribbean by the late Eocene-early Oligocene (Delsuc et al., 2019; Presslee et al., 2019), which is supported by the presence of an unnamed species from the early Oligocene of Puerto Rico (MacPhee and Iturralde-Vinent, 1995). The sloths subsequently evolved into distinct clades that were present on these islands for nearly 35 million years, until their extinction ca. $4 \mathrm{Ma}$ (Iturralde-Vinent and MacPhee, 1999; Steadman et al., 2005; MacPhee et al., 2007; Presslee et al., 2019). This radiation includes species with distinctive ecomorphologies that range

*Corresponding author. from large ground sloths, such as Megalocnus rodens Leidy, 1868 (<173 kg), to smaller arboreal species, such as Neocnus toupiti MacPhee, White, and Woods, $2000(<3 \mathrm{~kg})$ (White, 1993; MacPhee et al., 2000). Although the taxonomy of megalonichids is still in progress, currently 11 species classified in five genera of Pleistocene-Holocene megalocnids are recognized. Cuba had at least four species (Acratocnus antillensis [Matthew, 1931], Megalocnus rodens, Mesocnus browni Matthew, 1931, and Neocnus gliriformis [Matthew, 1931]), Hispaniola had six species (Acratocnus simorhynchus Rega et al., 2002, A. ye MacPhee, White, and Woods, 2000, N. comes [Miller, 1929], N. dousman MacPhee, White, and Woods, 2000, N. toupiti, and Parocnus serus Miller, 1929), and Puerto Rico had only one species (A. odontrigonus Anthony, 1916) (Silva-Taboada et al., 2007; McAfee and Beery, 2021). The species B and C recorded for Cuba by White and MacPhee (2001) and Delsuc et al. (2019) are referable species already known from the island (Silva-Taboada et al., 2007). Older Cenozoic fossils are very rare: only one proximal epiphysis of a femur is known from the early Oligocene of Puerto Rico (MacPhee and IturraldeVinent, 1995), and several elements from the early Miocene of Cuba have been assigned to Imagocnus zazae MacPhee and Iturralde-Vinent, 1994 (MacPhee et al., 2003). The scarcity of pre-Quaternary sloth fossils from the Greater Antilles has greatly 
limited our understanding of the paleobiogeography and diversity of the group.

Since the discovery of fossil sloths in the West Indies in the nineteenth century, researchers have relied on vicariance or overwater dispersal to explain the origin and inter-island distribution of this group (Silva-Taboada et al., 2007). Although current evidence supports an overlap in time between the arrival of sloths to the islands and the existence of a possible landspan between northern South American and the Greater Antilles, known as GAARlandia, little or no consensus has been reached regarding the interisland pattern of distribution of the genera and species (MacPhee et al., 2000; Rega et al., 2002; Davalos, 2004; SilvaTaboada et al., 2007; Philippon et al., 2020; Cornée et al., 2021).

Recent field work in two late Miocene-early Pliocene outcrops in the Dominican Republic led to the discovery of a partial tibia and scapula of a megalocnid sloth. The tibia is referred to Megalocnidae instead of Megalonychidae based on the characteristic strait shaft, proportionally deeper distal epiphysis, the presence of a discoid facet wider than the odontoid facet, and the most-posterior placement of the fibular facet (MacPhee et al., 2000). The specimen can be further referred to the subfamily Megalocninae on the basis of the presence of a prominent interfacet eminence and the clear distinction between the discoid and odontoid facets.

These remains represent the oldest record of a sloth on the island of Hispaniola and of any mammal described from nonamber-bearing deposits. All previous reports of this family on the islands were from Pleistocene-Holocene deposits (IturraldeVinent, 2001; McAfee and Beery, 2021). The new fossils provide fresh insights into the puzzling evolutionary history of Megalocnidae by filling a temporal gap between the early Miocene Imagocnus and the well-documented Pleistocene-Holocene taxa. Although the two specimens are not adequate for a formal diagnosis, they likely belong to an undescribed species of megalocnid sloth, closely related with Megalocnus from the Quaternary of Cuba, with features that suggest they may be related to this genus.

\section{Geological settings}

The collecting sites are located along Highway Juan Pablo II (RD-7) in the vicinity of the Parque Nacional Los Haitises (Fig. 1), northeastern Dominican Republic. The Haitises area exposes carbonate-siliciclastic ramp sequences that unconformably overlie and onlap Cretaceous-Paleogene igneous basement (Cordillera Oriental). The ramp system includes nearshoremarine, organic-rich sandstone and shale facies (Yanigüa Formation) that transition laterally to shallow-water carbonate facies of the Los Haitises Formation (Iturralde-Vinent, 2001; Braga et al., 2012; Core, 2015).

The scapula (MNHNSD FOS 25.1010) was collected at the top-middle section of outcrop the Paleo Pond $1\left(18^{\circ} 54^{\prime} 33.07^{\prime \prime} \mathrm{N}\right.$, $69^{\circ} 44^{\prime} 36.75^{\prime \prime} \mathrm{W}$ ), whereas the tibia was collected at the top of the section at the outcrop Paleo Pond $2\left(18^{\circ} 55^{\prime} 2.16^{\prime \prime} \mathrm{N}, 69^{\circ}\right.$ $44^{\prime} 6.06^{\prime \prime} \mathrm{W}$ ) (Core, 2015). Both outcrops are $\sim 5 \mathrm{~m}$ thick, 140 $150 \mathrm{~m}$ long, and are located at Kilometer 55 of Highway RD-7 near Sabana Grande de Boya (Fig. 1).

The basal Paleo Pond 1 (PP1) section shows an up to 1-m-thick bioclastic packstone facies capped by a sharp, erosional subaerial exposure surface with local caliche and oxidation. The exposure surface is overlain by a 1.5 -m-thick unit composed of clay-rich wackestone facies with abundant vertebrate fossils (e.g., pelomedusoid turtles), large benthic foraminiferans (e.g., soritids), and bivalve and gastropod fragments. The clay-rich wackestone facies is overlain by a $30-\mathrm{cm}$-thick layer consisting of fossiliferous silty sandstone facies with abundant large benthic foraminiferans, sandstone pebbles, and vertebrate fossils, including gavialoid crocodilian teeth and fish remains (Core, 2015). The fossiliferous silty sandstone facies is overlain by a 2.2-m-thick, clay-rich wackestone facies with large benthic foraminiferans and marine bivalves and gastropods.

The basal Paleo Pond 2 (PP2) section shows a 2.7-m-thick unit compose of bioclastic packstone facies intercalated with bioclastic wackestone facies capped by a sharp, erosional subaerial exposure (SB3) surface that correlates laterally with PP1. The exposure surface is also overlain by a 2.2 -m-thick unit composed of clay-rich wackestone facies with abundant vertebrate fossils (e.g., pelomedusoid turtles), large benthic foraminiferans (e.g., soritids), bivalves, and gastropod fragments.

These marine invertebrate assemblages combined with the abundance of vertebrate fossils, including an undescribed rodent, a gavialoid, and pelomedusoid turtles, suggest an estuarine environment $(0-10 \mathrm{~m}$ water depth) that was developed during relative sea-level rise and initial transgression after subaerial exposure (Core, 2015). Sr isotope-derived mean ages from marine bivalves (Kuphus incrassatus Gabb, 1873) located stratigraphically below and above the units of interest in this study indicate a late Miocene to early Pliocene age (ca. 7.15-5.57 Ma, Messinian-Zanclean) for the described units (Core, 2015; Ortega-Ariza et al., 2015).

\section{Materials and methods}

Specimens examined.-Acratocnus antillensis, left tibia (UCLVP-66, CWS-309); Acratocnus ye left (UF 170185, 170333) and right tibiae (UF 170335, 315688); Bradypus tridactylus Linnaeus, 1758, partial skeleton (UF 8123); Megalocnus rodens, associated mandible, right and left humeri, left ulna, radius, femur, and tibia (CZACC 26.296), left (ARQC-159, 172), and right scapulae (ARQC-160), left (ARQC-135, 140, 141, 155) and right tibiae (ARQC-137, 168); Megalonyx leptostomus Cope, 1893, right tibia (UF 223808, 274300); M. jeffersoni Desmarest, 1822, right tibia (23569); $M$. wheatleyi Cope, 1871, left tibia (UF 21345); Mesocnus browni, left (CWS-1023) and right tibiae (CLV-1125); Neocnus comes, associated right and left tibiae, right fibula, right and left astragali, and right calcaneus (UF 170440), left (UF-170323, 170444) and right tibiae (UF-170324, 170446); N. dousman, left tibia (UF 170404); N. gliriformis, left (CWS-901E) and right tibiae (ARQC-108); Parocnus serus, right (UF 23863) and left tibiae (UF-170080, 169953); Pliometanastes protistus Hirschfeld and Webb, 1968, left tibia (UF 95400).

Measurements._-All measurement were made with a Mitutoyo caliper with a $0.01 \mathrm{~mm}$ resolution (Absolute Solar Digimatic) and followed the measurements used by Silva-Taboada et al. (2007). 


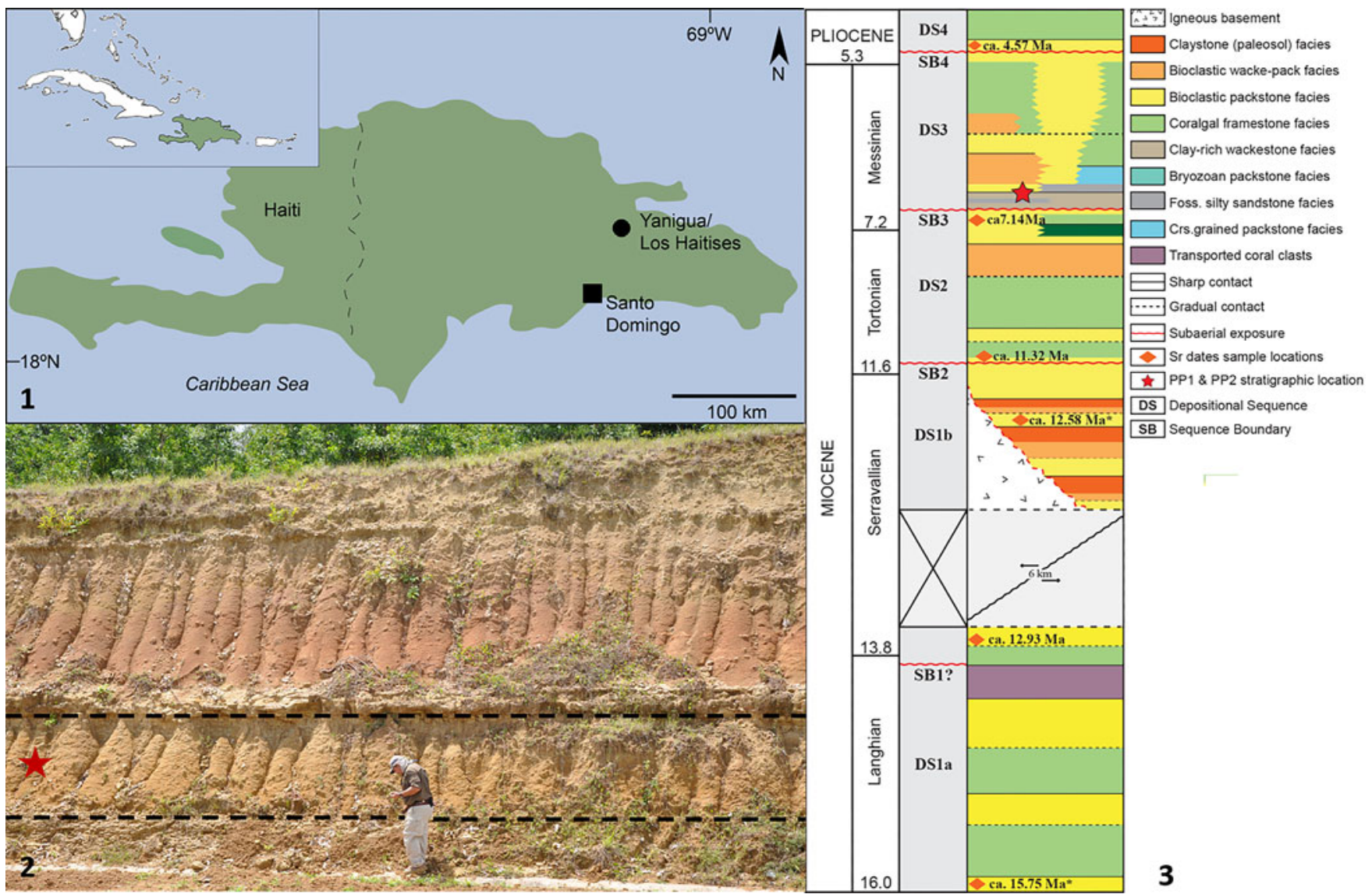

Figure 1. Map of Hispaniola (1) indicating the general location of Yanigua/Los Haitises locality in northeastern Dominican Republic, where the outcrops PP1 and PP2 are located. In the photograph of outcrop PP1 (2), the red star indicates the bed from which one of the specimens was recovered; the dashed lines mark the upper and lower boundaries of the bed. (3) Generalized stratigraphic section of the Haitises area with the red star at the stratigraphic position of PP1 and PP2 study outcrops. The orange diamonds indicate the dated locations and ages derived from strontium dates; (*) indicates Sr ages from Ortega-Ariza et al. (2015).

Repositories and institutional abbreviations.-ARQC, collection of the former Arqueocentro, housed at Universidad Central de las Villas, Villa Clara, Cuba; CLV, field number from Lazaro Vinola, Cuba; CWS, Colección William Suarez, housed at Museo Nacional de Historia Natural de Cuba, La Havana, Cuba; CZACC, Instituto de Ecología y Sistemática, La Havana, Cuba; MNHNCu Museo Nacional de Historia Natural de Cuba, La Havana, Cuba; MNHNSD FOS, Vertebrate Paleontology Collection of Museo Nacional de Historia Natural, Santo Domingo, Dominican Republic; UCLVP, Universidad Central de las Villas, Villa Clara, Cuba; UF, Vertebrate Paleontology Collection, Florida Museum of Natural History, Gainesville, Florida, USA.

\section{Systematic paleontology}

Superorder Xenarthra Cope, 1889

Suborder Folivora Delsuc et al., 2001

Oder Pilosa Flower, 1883

Family Megalocnidae Kraglievich, 1923

Subfamily Megalocninae Kraglievich, 1923

Megalocninae Kraglievich, 1923

Megalocninae gen. et sp. indet.

Figures 2-4.1
Occurrence.-The specimens come from two outcrops separated by $3.5 \mathrm{~km}$, both located along the Juan Pablo II (RD7) highway on Sabana Grande de Boya, Dominican Republic (Fig. 1). The scapula was collected at locality PP1 $\left(18^{\circ} 54^{\prime} 33.0768^{\prime \prime} \mathrm{N}, 69^{\circ} 44^{\prime} 36.7578^{\prime \prime} \mathrm{W}\right)$, whereas the tibia comes from locality PP2 $\left(18^{\circ} 56^{\prime} 15.118^{\prime \prime} \mathrm{N}, 69^{\circ} 44^{\prime} 27.842^{\prime \prime} \mathrm{W}\right)$. Both outcrops belong to the upper section of the Yanigüa-Los Haitises Formation.

Description and comparison.-MNHNSD FOS 25.4251 consist of the distal half of a right tibia of a medium-sized sloth with numerous fractures in the diaphysis, partially compressed near the epiphysis, and missing most of the posterior section of the distal articular surface. Although the specimen is somewhat deformed, it is still possible to identify several potentially taxonomically informative characteristics. The fusion of the distal epiphysis with the diaphysis suggests that it belong to an adult individual. The specimen is larger than the tibia of Neocnus and Acratocnus Anthony, 1916, and smaller than that of Megalocnus Leidy, 1868, but falls within the size range of Mesocnus Matthew, 1931, and Parocnus Miller, 1929 (Anthony, 1918; Matthew and Paula-Couto, 1959; Silva-Taboada et al., 2007). In MNHNSD FOS 25.4251, the cross-section of the diaphysis near the midpoint 


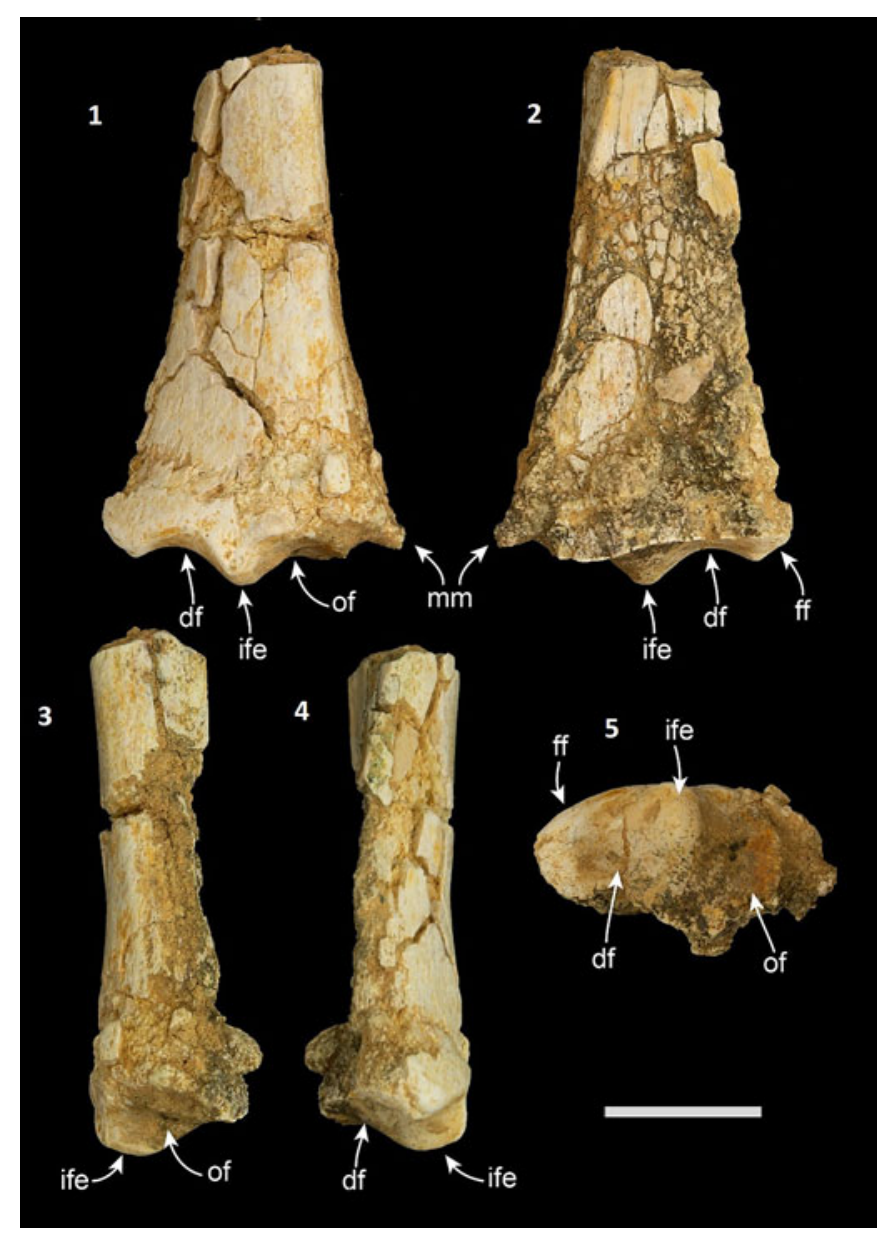

Figure 2. Right tibia of Megalocninae gen. and sp. indet. (MNHNSD FOS 25.4251) from the late Miocene-early Pliocene of the Dominican Republic in anterior (1), posterior (2), medial (3), lateral (4), and distal views (5). Abbreviations: df, discoid facet; ff, fibula facet; ife, interfacet eminence; mm, medial malleolus; of, odontoid facets. Scale bar equals $2 \mathrm{~cm}$.

of the tibia is "D-shaped," with a nearly flat posterior and convex anterior surface slightly skewed medially. The diaphysis is nearly as wide $(18.9 \mathrm{~mm})$ as it is deep $(17.1 \mathrm{~mm})$ around the midsection, with sharp posterolateral and posteromedial margins. Megalocnus, Parocnus, and Mesocnus differ in having an oval diaphysis in cross-section, a significantly wider than deep shaft, and the posterolateral and posteromedial margin of the diaphysis are not sharp. The diaphysis of

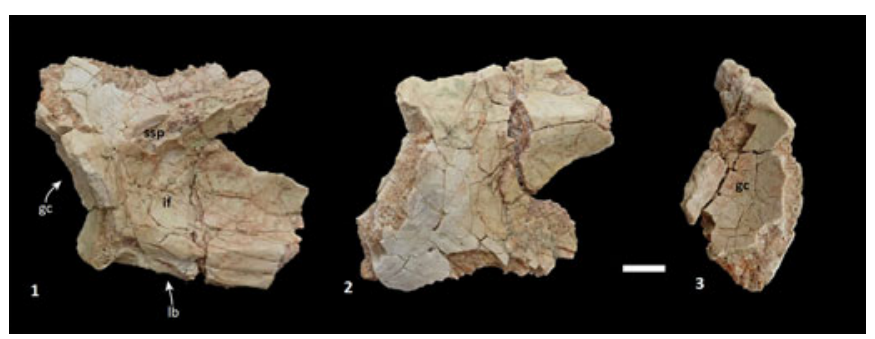

Figure 3. Left scapula of Megalocninae gen. and sp. indet. (MNHNSD FOS 25.1010) from the late Miocene-early Pliocene of the Dominican Republic in dorsal (1), ventral (2), and proximal views (3). Abbreviations: gc, glenoid cavity; if, infraspinous fossa; $1 b$, lateral border; ssp, scapular spine. Scale bar equals $1 \mathrm{~cm}$.
Megalocnus curves medially, unlike that of MNHNSD FOS 25.4251, but some of the differences in the shape of the diaphysis observed between two taxa can be found among species of the same genus in other West Indies sloths (e.g., Neocnus comes vs. $N$. dousman). The shaft of the tibia in Neocnus Arredondo, 1961, and Acratocnus is similar to that of MNHNSD FOS 25.4251 in being relatively narrow with respect to the distal epiphysis, but in some species of these genera (e.g., Necosnus comes and Acratocnus antillensis) the diaphysis has a D-shaped cross section with sharp posterolateral and posteromedial margin. The width of the shaft of MNHNSD FOS 25.4251 increases steadily towards the distal epiphysis with a slight increment in the slope of the medial plane at about the half point of the specimen. The maximum width of the distal epiphysis is $\sim 42.9 \mathrm{~mm}$, but it may be slightly wider considering that the specimen is partially eroded. The anterolateral surface of MNHNSD FOS 25.4251 is convex, and no evidence of torsion of the diaphysis is present, in contrast with Parocnus where the distal and proximal epiphysis of the tibia are rotated with respect to each other, resulting in a lateral torsion of the diaphysis. The anterior surface near the epiphysis is continuous, lacking the pivot for the articulation of the navicular process of the astragalus, which is present only in the species of Mesocnus.

The articular surface of the tibia in MNHNSD FOS 25.4251 is partially preserved and possesses a prominent interfacet eminence that separates anteriorly the discoid and odontoid facets. The eminence is broad and high, its long axis is anteroposteriorly oriented, and it is located near the center of the articular surface, towards its anterior margin. The interfacet eminence seems to be associated in some continental sloths, as in Megatheriidae and Nothrotheriidae, with the medial ridge that separates the discoid and odontoid facets, but such a ridge is absent in MNHNSD FOS 25.4251 and other Greater Antilles sloths (Amson et al., 2015; Toledo et al., 2015, 2018). In Megalocnus, the interfacet eminence does not extend posteriorly as in MNHNSD FOS 25.4251. In Mesocnus and Parocnus, the interfacet eminence is located more medially and internally on the articular surface, whereas in Acratocnus and Neocnus the eminence is extremely reduced. The discoid and odontoid facets in MNHNSD FOS 25.4251 are concave and possess similar depth in anterior view, as in Megalocnus. In distal view, the posteromedial region of the discoid facet seems to be more expanded and deeper than that of the anterior portion. The odontoid facet has an oval outline and is oriented anteroposteriorly, but it does not expand as far posteriorly as the discoid facet. In the smaller Caribbean taxa, Neocnus and Acratocnus, the odontoid and discoid facet are also at the same level, but almost undifferentiated. In MNHNSD FOS 25.4251, a smaller eminence separates anteriorly the fibular and discoid facet, but only a reduced section of the former facet is preserved on the specimen. The fibular facet is relatively narrow and longer than wide. Just proximal to the odontoid facet, on the medial side of the specimen, there is a small remnant of the medial malleolus, which is separated from the facet by a wide groove, as in other Caribbean taxa, except in Parocnus in which the medial malleolus and the groove are reduced. Poorly defined grooves in MNHNSD FOS 25.4251, interpreted here as marking the 


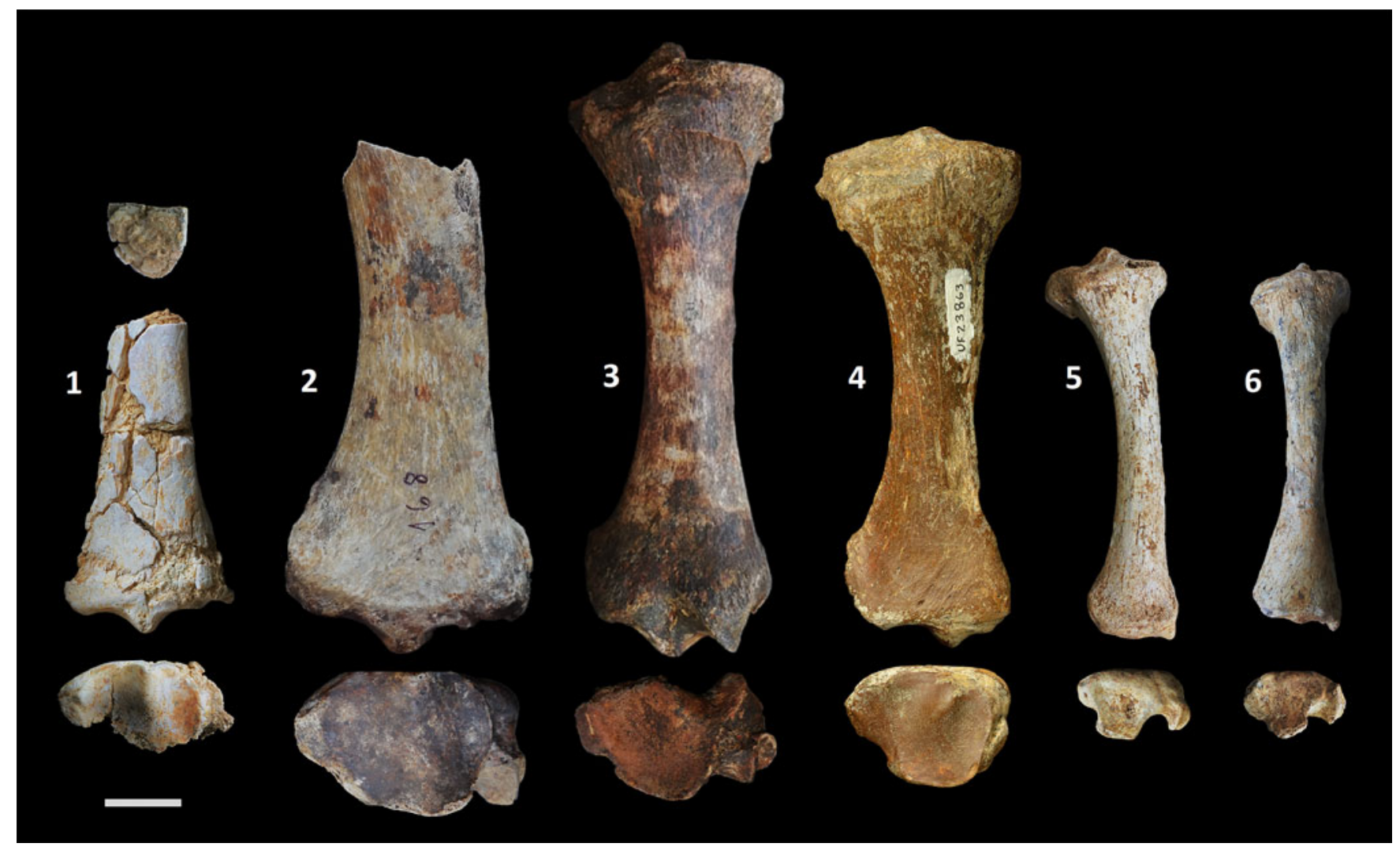

Figure 4. Comparison of the Yanigüa-Los Haitises megalocnid with Quaternary genera from the Greater Antilles. Megalocninae gen. and sp. indet. (1), partial right tibia (MNHNSD FOS 25.4251) in proximal (top), anterior (middle), and distal (bottom) views; from left to right, anterior and distal (top to bottom) views of Megalocnus rodens (2), partial right tibia (ARQC-168) in anterior and distal views; Mesocnus browni (3), right tibia (CLV-1125) in anterior and distal views; Parocnus serus (4), right tibia (UF 23863) in anterior and distal views; Acratocnus ye (5), right tibia (UF 170335) in anterior and distal views, and Neocnus comes (6), left tibia (reversed; UF 170444), in anterior and distal views. Scale bar equals $2 \mathrm{~cm}$.

course of the flexor hallucis longus and the tibialis caudalis, are located on the posteromedial and medial side of the tibia, respectively. The two possible muscle scars are separated by an almost entirely lost medial malleolus, where a groove of the flexor digitorum longus was likely located (Amson et al., 2015; Toledo et al., 2015).

The scapula (MNHNSD FOS 25.1010) is fragmentary (Fig. 3), and only part of the glenoid cavity, spine, and lateral border is preserved. The specimen is assigned to a sloth because it is significantly larger than the scapula of any other terrestrial mammals known to occur in younger or older deposits in Hispaniola (e.g., rodents, solenodonotans, primates). It further differs from rodents, primates, eulipotyphlans, and sirenians by not having a constriction in the scapular neck between the glenoid cavity and the rest of the body of the scapula. The scapular spine is closer to the glenoid cavity, as in other sloths from the Greater Antilles. Other diagnostic characters are absent, and we can only conclude that it may belong to a sloth of the body size between Megalocnus and Parocnus.

Materials._Distal end of right tibia (MNHNSD FOS 25.4251) (Figs. 2, 4.1) and proximal region of left scapula (MNHNSD FOS 25.1010) (Fig. 3) of a medium-sized sloth.

Remarks. - This late Miocene sloth from Hispaniola differs morphologically from all Quaternary genera known from the
Greater Antilles, but can be referred to the subfamily Megalocninae because of the presence of a prominent interfacet eminence and the clear distinction between the discoid and odontoid facets. Its morphology further suggests that it may had been closely related with Megalocnus from Cuba. On the other hand, the gracility of the diaphysis of MNHNSD FOS 25.4251 resembles that of Acratocnus, Neocnus, and arboreal species, but the morphology of the distal epiphysis suggests a more terrestrial habitat.

\section{Discussion and conclusions}

The morphology of the distal end of the tibia of sloths is regulated by functional and phylogenetic constrains (White and MacPhee, 2001; Silva-Taboada et al., 2007; McDonald, 2012). The wide range of niches occupied by members of the suborder Folivora and their locomotion modes resulted in the evolution of very complex morphologies. In the Greater Antilles, the tibia of Mesocnus is among the most peculiar ones. It bears a deep depression for articulation of the navicular process of the astragalus at the middle of the anterodistal surface of the tibia; this feature is absent in other Caribbean sloths. Although Mesocnus has been considered a junior synonym of Parocnus (MacPhee et al., 2000), the skeletal differences among the Cuban and Hispaniola taxa indicate that they belong to different genera. 
In the large sloths from the Greater Antilles, the position and morphology of the navicular facet on the tibia and its articulation with the astragalus probably restricted the eversion and inversion of the pes, but extended range of the flexion. The interfacet eminence, like the medial ridge, limited the lateral and medial displacement between the astragalus and tibia, giving more stability to the pes, which seems to be exacerbated in Mesocnus. The robustness of the diaphysis of the tibia, articulation between the tibia and astragalus, and the presence of many other traits in the rest of the postcranial skeleton argue in favor of a more terrestrial locomotion for Megalocnus, Mesocnus, and Parocnus (White and MacPhee, 2001; Silva Taboada et al., 2007; Arredondo Antúnez, 2011). In contrast, the lack of differentiation of the articular facets on the distal epiphysis on the tibia of Neocnus and Acratocnus is associated with arboreal species. Furthermore, Acratocnus and Neocnus share a remarkably large grove for the flexor hallucis longus tendon, which is also present in some extinct continental taxa, such as santacrucian genera Hapalops Ameghino, 1887, and Eucholoeops Ameghino, 1887, and the extant Bradypus (Toledo et al., 2015). Other authors have previously noted the similarity among the postcranial skeletons of Hapalops, Eucholoeops, Acratocnus, and Neocnus (Anthony, 1916; De Iuliis et al., 2014), suggesting it is possibly related to a shared arboreal or climber ecology (Braga et al., 2012; Toledo, 2016).
Recent molecular studies suggest that Greater Antilles sloths are a clade that arrived in the Caribbean by the Eocene-Oligocene boundary, where it evolved and diversified in isolation for more than 35 million years (Delsuc et al., 2019; Presslee et al., 2019). A Paleogene origin agrees with the age proposed for the GAARlandia hypothesis (IturraldeVinent and MacPhee, 1999; Philippon et al., 2020), which suggests sloths and other terrestrial elements of the Greater Antilles biota would have colonized the region ca. $35 \mathrm{Ma}$ across a transient aerial exposure of land that connected some islands with northern South America. Additional molecular and paleontological evidence seems consistent with this hypothesis, or at least suggests a synchronous colonization of the region by other terrestrial taxa (Alonso et al., 2012; Vélez-Juarbe et al., 2014; Chamberland et al., 2018; Blackburn et al., 2020; Marivaux et al., 2020). The oldest fossil referable to a sloth in the Greater Antilles is a proximal end of a small femur from the early Oligocene of Puerto Rico (MacPhee and Iturralde Vinent, 1995) that may belong to the smallest folivoran known. In contrast, the early Miocene Imagocnus zazae from Cuba reached a large body size, probably close to or larger than Megalocnus $(\sim 270 \mathrm{~kg})$ (MacPhee and Iturralde-Vinent, 1994, 1995). Although a number of other fossils have been referred to Imagocnus zazae (MacPhee et al., 2003), a wide range of body sizes, ranging from a humerus about the size of an Acratocnus

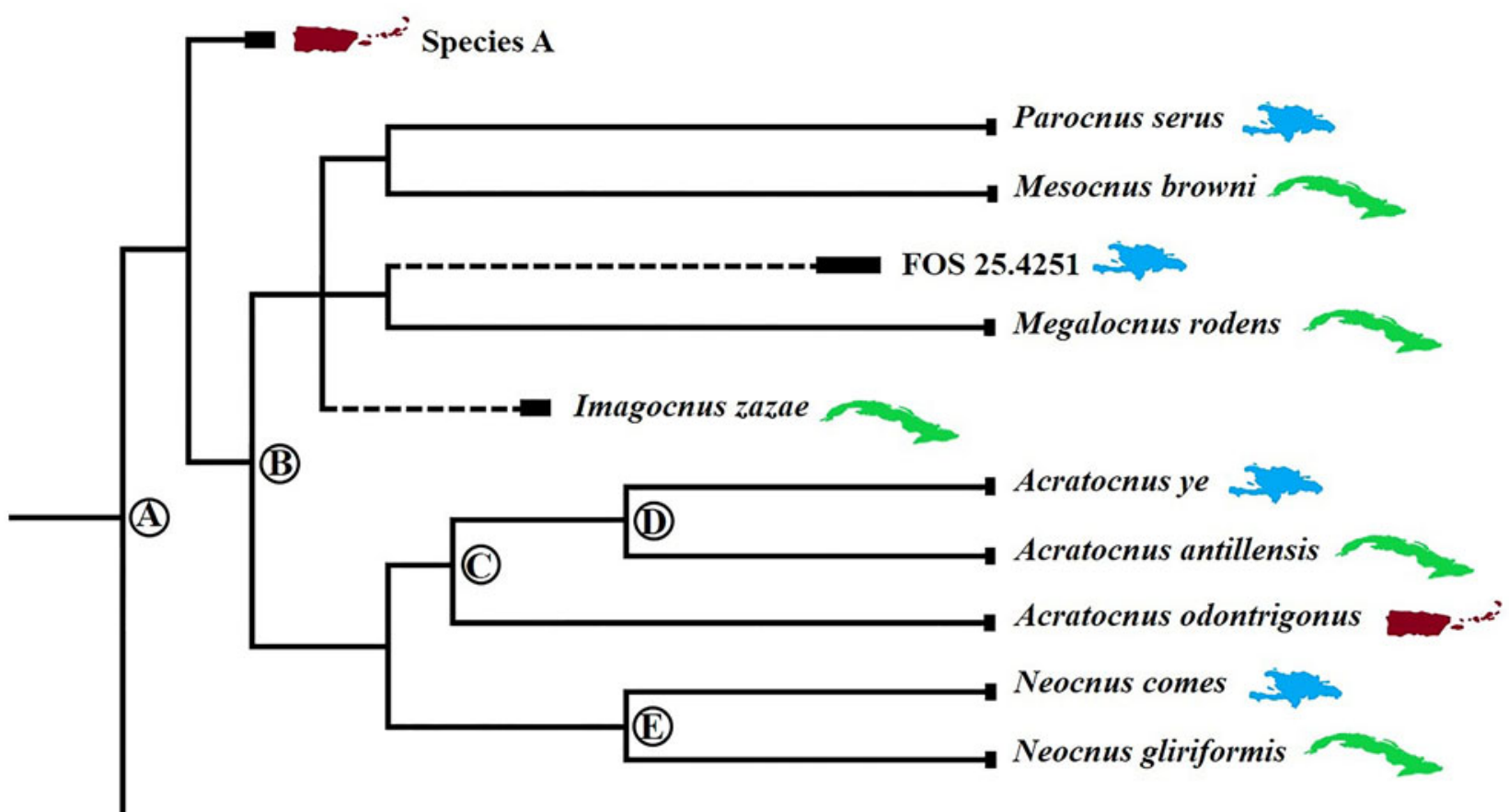

Megatherioidea/Mylodontoidea

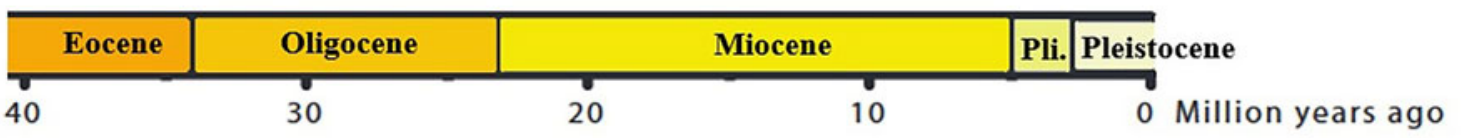

Figure 5. Proposed relationships of Greater Antillean sloths based on White and MacPhee (2001) and Delsuc et al. (2019). Nodes A, C, D, and E are based on the interisland split pattern and ages of Cuba-Hispaniola-Puerto Rico proposed by Iturralde-Vinent (2006), whereas node B followed the proposed calibrated age for the split between Acratocnus and Parocnus (Delsuc et al., 2019). The dashed branches are for taxa that have not been included in any phylogenetic reconstruction until now. Notice that Hispaniola and Cuba shared most of the diversity of sloths in the Greater Antilles. 
humerus to a pelvis comparable with that of Megalocnus, suggests that the sample may be composed of more than one taxon, even when taking sexual dimorphism into account. Imagocnus zazae has a combination of characters that are also found in Megalocnus and/or Parocnus, but most of its skeleton is poorly known and its phylogenetic relationships remain poorly resolved. The specimens described here (MNHNSD FOS 25.4251 and MNHNSD FOS 25.1010) belong to an undescribed new taxon that inhabited the northern paleoisland of Hispaniola when the Greater Antilles were already separated from each other and fills a temporal gap between Imagocnus and the Quaternary species. The fossils of this undescribed species, along with those of Imagocnus zazae from Cuba, suggest the presence of multiple lineages of sloths across the Greater Antilles during the Neogene that disappeared before the late Quaternary.

The occurrence of sister taxa on different islands in the Greater Antilles during the late Pleistocene (Fig. 5) has been interpreted either as the result of Quaternary overwater dispersal (Rega et al., 2002; Silva-Taboada et al., 2007) or vicariance during the Neogene (Iturralde-Vinent and MacPhee, 1999; MacPhee et al., 2003). Some authors supporting the former hypothesis argue that separation of populations since the early Miocene or before should have resulted in more than just species level diversification (Simpson, 1956; Rega et al., 2002; Silva-Taboada et al., 2007). In agreement with the molecular results, remains of pre-Quaternary sloths from Puerto Rico, Cuba, and now Hispaniola support the existence of the group starting in the early Oligocene, through the late Holocene (Fig. 5). Whether some of these older forms represent taxa closely related to the Quaternary species or other extinct branches of the megalocnid radiation in the region is still unknown. If the split-up of the Greater Antilles core islands (Puerto Rico-Hispaniola-Cuba) during the Neogene, coupled with extinction of some lineages, caused the distribution patterns observed in the Pleistocene-Holocene, then fossils of the clades shared among islands should be found in Neogene deposits, which does not seem to be the case. On the other hand, if overwater dispersal among Puerto Rico, Cuba, and Hispaniola was prevalent during the Quaternary, we would expect to find them also in the Bahamas, Jamaica, or some of the offshore islands in the Greater Antilles, especially given that good dispersers such as some rodents, frogs, lizards, and snakes did colonize these regions repeatedly (Hedges, 2006). However, intense fossil collecting on those islands has not yielded fossils of sloths from the Quaternary (Silva-Taboada et al., 2007). The current pre-Quaternary fossil record of the group is rather limited and fragmentary, and it is necessary to incorporate more molecular results from recently extinct taxa.

Although efforts aimed at collecting fossils of terrestrial vertebrates in Neogene localities are ongoing (e.g., Rio Guatemala in Puerto Rico; Vélez-Juarbe et al., 2014; Blackburn et al., 2020; Marivaux et al., 2020, 2021), future fieldwork in Hispaniola and across the Greater Antilles is needed. Filling the temporal and geographical gaps in the fossil record between the Eocene-Oligocene and the Quaternary terrestrial fauna would lead to an improved understanding of the origins and evolution of sloths and other components of the Greater Antillean vertebrate fauna. The fossils herein described represent the oldest sloth known from Hispaniola, implying that this group was present in the island at least since the late Miocene-early Pliocene.

\section{Acknowledgments}

We are thankful to W. Suarez, J. Martinez, and Y. Ceballos for their thoughtful insights and suggestions during the elaboration of the manuscript. We also extend our gratitude to the Museo Nacional de Historia Natural Prof. Eugenio de Jesús Marcano for their support and to K.I. Velez-Rosado (UM) and H. Santos-Mercado (UPRM) for the locality photo in Figure 1 and their help during field work. The early version of the manuscript was improved by the comments and suggestions of the editors J. Calede and H.D. Sues, an anonymous reviewer, and F. Pujos, to whom we express our most sincere gratitude.

\section{References}

Alonso, R., Crawford A.J., and Bermingham E., 2012, Molecular phylogeny of an endemic radiation of Cuban toads (Bufonidae: Peltophryne) based on mitochondrial and nuclear genes: Journal of Biogeography, v. 39, p. 434-451.

Ameghino, F., 1887, Enumeración sistemática de las especies de mamíferos fósiles coleccionados por Cárlos Ameghino en los terrenos eocenos de la Patagonia: Boletín del Museo de La Plata, v.1, p. 1-26.

Amson, E., Argot, C., McDonald, H.G., and De Muizon, C., 2015, Osteology and functional morphology of the hind limb of the marine sloth Thalassocnus (Mammalia, Tardigrada): Journal of Mammalian Evolution, v. 22, p. $355-419$.

Anthony, H.E., 1916, Preliminary report on fossil materials from Porto Rico, with descriptions of a new genus of ground sloth and two new genera of hystricomorph rodents: Annals of the New York Academy of Sciences, v. 27, p. 193-203.

Anthony, H.E., 1918, The indigenous land mammals of Porto Rico, living and extinct: Memoirs of the American Museum of Natural History, v. 2, p. 333-435.

Arredondo, O.P., 1961, Descripciones preliminares de dos nuevos géneros y especies de edentados del Pleistoceno cubano: Boletín del Grupo de Exploraciones Cientificas, v. 1, p. 9-40.

Arredondo Antúnez, C., 2011, Los perezosos extinctos, in Borroto-Paez, R.B., and Mancina, C.A., eds., Mamiferos en Cuba: Vaasa, Finland, UPC Print, p. $28-37$.

Blackburn, D.C., Keeffe, R.M., Vallejo-Pareja, M.C., and Vélez-Juarbe, J., 2020, The earliest record of Caribbean frogs: a fossil coquí from Puerto Rico: Biological Letters, v. 16, 20190947. https://doi.org/10.1098/rsbl. 2019.0947.

Braga, J.C., Díaz de Neira, A., Lasseur. E., Mediato, J., Aguirre, J., Abad, M., Hernaiz-Huerta, P.P., Monthel, J., Perez-Valera, F., and Lopera, E., 2012, Pliocene-Lower Pleistocene shallow-water mixed siliciclastics and carbonates (Yanigua and Los Haitises formations) in eastern Hispaniola (Dominican Republic): Sedimentary Geology, v. 265, p. 182-194.

Chamberland, L., McHugh, A., Kechjian, S., Binford, G.J., Bod, J.E., Coddington, J., Dolman, G., Hamilton, C.A., Harvey, M.S., Kuntner, M., and Agnarsson, I., 2018, From Gondwana to GAARlandia: evolutionary history and biogeography of ogre-faced spiders (Deinopis): Journal of Biogeography, v. 45, p. 2442-2457.

Cope, E.D., 1871, Preliminary report on the Vertebrata discovered in the Port Kennedy Bone Cave: Proceedings of the American Philosophical Society, v. 12 , p. 73-102.

Cope, E.D., 1889, The Edentata of North America: The American Naturalist, v. 23, p. 657-664.

Cope, E.D., 1893, A preliminary report on the vertebrate paleontology of the Llano Estacado: Annual Reports of the Geological Survey of Texas, v. 4, p. $1-136$.

Core, E.E., 2015, High Resolution Sequence Stratigraphy of Neogene, Mixed Carbonate-Siliciclastic System, Los Haitises National Park, Northeastern Dominican Republic [M.Sc. thesis]: Mayagüez, Puerto Rico, University of Puerto Rico-Mayagüez, $100 \mathrm{p}$.

Cornée, J.J., Münch, P., Philippon, M., BouDagher-Fadel, M., Quillévéré, F., Melinte-Dobrinescu, M., Lebrun, J.F., et al., 2021, Lost islands in the northern Lesser Antilles: possible milestones in the Cenozoic dispersal of terrestrial organisms between South-America and the Greater Antilles: Earth-Science Reviews, 103617. https://doi.org/10.1016/j.earscirev.2021.103617. 
Davalos, L.M., 2004, Phylogeny and biogeography of Caribbean mammals: Biological Journal of the Linnean Society, v. 81, p. 373-394.

De Iuliis, G., Pujos, F., Toledo, N., Bargo, M.S., Vizcaíno, S.F., 2014, Eucholoeops Ameghino, 1887 (Xenarthra, Tardigrada, Megalonychidae) from the Santa Cruz Formation, Argentine Patagonia: implications for the systematics of Santacrucian sloths: Geodiversitas, v. 36, p. 209-255.

Delsuc, F., Catzeflis, F.M., Stanhope, M.J., and Douzery, E.J.P., 2001, The evolution of armadillos, anteaters and sloths depicted by nuclear and mitochondrial phylogenies: implications for the status of the enigmatic fossil Eurotamandua: Proceedings of the Royal Society of London B: Biological Sciences, v. 268, p. 1605-1615.

Delsuc, F., Kuch, M., Gibb, G.C., Karpinski, E., Hackenberger, D., Szpak, P., Martínez, J.G., et al., 2019, Ancient mitogenomes reveal the evolutionary history and biogeography of sloths: Current Biology, v. 29, p. 2031-2042.

Desmarest, A.G., 1822, Mammalogie ou Description des Especes de Mammiferes. v. 2: Paris, Chez Mme. Veuve Agasse, 555 p.

Flower, W.H., 1883, On the arrangement of the orders and families of existing Mammalia: Proceedings of the Zoological Society of London, v. 51, p. $178-186$

Gabb, W.M., 1873, On the topography and geology of Santo Domingo: American Philosophical Society, v. 15 , p. 49-259

Hedges, S.B., 2006, Paleogeography of the Antilles and origin of West Indian terrestrial vertebrates: Annals of the Missouri Botanical Garden, 93, p. 231-244.

Hirschfeld, S.E., and Webb, S.D., 1968, Plio-Pleistocene megalonychid sloths of North America: Bulletin of the Florida State Museum, v. 12, p. 213-296.

Illiger, K., 1811, Prodromus Systematis Mammalium et Avium: Berlin, Salfeld, $301 \mathrm{p}$.

Iturralde-Vinent, M.A., 2001, Geology of the amber-bearing deposits of the Greater Antilles. Caribbean Journal of Science, v. 37, p. 141-167.

Iturralde-Vinent, M.A., 2006, Meso-Cenozoic Caribbean paleogeography: implications for the historical biogeography of the region: International Geology Review, v. 48, p. 791-827.

Iturralde-Vinent, M.A., and MacPhee, R.D., 1999, Paleogeography of the Caribbean region: implications for Cenozoic biogeography: Bulletin of the American Museum of Natural History, v. 238, p. 1-95.

Kraglievich, L., 1923, Descripción de dos cráneos y otros restos del género Pliomorphus Ameghino procedentes de la Formación Entrerriana de las barrancas del Río Paraná: Anales del Museo Nacional de Historia Natural de Buenos Aires, v. 23, p. 1-56.

Leidy, J., 1868, Notice of some vertebrate remains from the West Indian islands: Proceedings of the Academy of Natural Sciences of Philadelphia, v. 20, p. $178-180$.

Linnaeus, C., 1758, Systema Naturae per Regna Tria Naturae. Secundum Classis, Ordines, Genera, Species, Cum Characteribus, Differentiis, Synonymis, Locis, v. 1: Stockholm, Laurentii Salvii, 824 p.

MacPhee, R.D., and Iturralde-Vinent, M.A., 1994, First Tertiary land mammal from Greater Antilles: an early Miocene Sloth (Xenarthra, Megalonychidae) from Cuba: American Museum Novitates, v. 3094, p. 1-13.

MacPhee, R.D., and Iturralde-Vinent, M.A., 1995, Origin of the Greater Antillean land mammal fauna, 1 : new Tertiary fossils from Cuba and Puerto Rico: American Museum Novitates, v. 3141, p. 1-31.

MacPhee, R.D., White, J.L., and Woods, C.A., 2000, New megalonychid sloths (Phyllophaga, Xenarthra) from the Quaternary of Hispaniola: American Museum Novitates, v. 3303, p. 1-32.

MacPhee, R.D., Iturralde-Vinent, M.A., and Gaffney, E., 2003, Domo de Zaza, an early Miocene vertebrate locality in south-central Cuba, with notes on the tectonic evolution of Puerto Rico and the Mona Passage: American Museum Novitates, v. 3394, p. 1-42.

MacPhee, R.D., Iturralde-Vinent, M.A., and Vázquez, O.J., 2007, Prehistoric sloth extinctions in Cuba: implications of a new "last" appearance date: Caribbean Journal of Science, v. 43, p. 94-98.

Marivaux, L., Vélez-Juarbe, J., Merzeraud, G., Pujos, F., Viñola López, L.W., Boivin, M., Santos-Mercado, H., et al., 2020, Early Oligocene chinchilloid caviomorphs from Puerto Rico and the initial rodent colonization of the West Indies: Proceedings of the Royal Society B, v. 287, 20192806. https://doi.org/10.1098/rspb.2019.2806.
Marivaux, L., Vélez-Juarbe, J., Viñola López, L.W., Fabre, P-H., Pujos, F., Santos-Mercado, H., Cruz, E.J., et al., 2021, An unpredicted ancient colonization of the West Indies by North American rodents: dental evidence of a geomorph from the early Oligocene of Puerto Rico: Papers in Palaeontology, v. 7, p. 2021-2039.

Matthew, W.D., 1931, Genera and new species of ground sloths from the Pleistocene of Cuba: American Museum Novitates, v. 511, p. 1-5.

Matthew, W.D., and Paula Couto, C., 1959, The Cuban edentates: Bulletin of the American Museum of Natural History, v. 117, p. 1-56.

McAfee, R.K., and Beery, S.M., 2021, Intraspecific variation of megalonychid sloths from Hispaniola and the taxonomic implications: Historical Biology, v. 33 , p. $371-386$.

McDonald, H.G., 2012, Evolution of the pedolateral foot in ground sloths: patterns of change in the astragalus: Journal of Mammalian Evolution, v. 19, p. 209-215.

Miller, G.S., 1929, A second collection of mammals from caves near St. Michel, Haiti: Smithsonian Miscellaneous Collections, v. 81, p. 1-30.

Ortega-Ariza, D. Franseen, E.K. Santos-Mercado, H., Ramírez-Martínez, W.R., and Core-Suárez, E.E., 2015, Strontium isotope stratigraphy for Oligocene-Miocene carbonate systems in Puerto Rico and the Dominican Republic: implications for Caribbean processes affecting depositional history: The Journal of Geology, v. 123, p. 539-560.

Philippon, M., Cornée, J-J., Münch, P., van Hinsbergen, D.J.J., BouDagherFadel, M., Gailler, L., Boschman, L.M., et al., 2020, Eocene intra-plate shortening responsible for the rise of a faunal pathway in the northeastern Caribbean realm: PLoS ONE, v. 15, e0241000. https://doi.org/10.1371/ journal.pone. 0241000 .

Presslee, P., Slater, G.J., Pujos, F., Forasiepi, A.M., Fischer, R., Molloy, K., Mackie, M., et al., 2019, Palaeoproteomics resolves sloth relationships: Nature Ecology \& Evolution, v. 3, p. 1121-1130.

Rega, E., McFarlane, D.A., Lundberg, J., and Christenson, K., 2002, A new megalonychid sloth from the late Wisconsinan of the Dominican Republic: Caribbean Journal of Science, v. 38, p. 11-19.

Silva-Taboada, G., Suárez Duque, W., and Díaz-Franco, S., 2007, Compendio de los Mamíferos Terrestres Autóctonos de Cuba Vivientes y Extinguidos: Ediciones Boloña, La Habana, Frienses, 465 p.

Simpson, G., 1956, Zoogeography of West Indian land mammals: American Museum Novitates, v. 1759, p. 1-28.

Steadman, D., Paul, S.M., MacPhee, R.D., Timothy Jull, A.J., McDonald, H.G., Woods, C.A., Iturralde-Vinent, M.A., and Hodgins, G.W.L., 2005, Asynchronous extinction of late Quaternary sloths on continents and islands: Proceedings of the National Academy of Sciences of the United States of America, v. 102, p. 11763-11768.

Toledo, N., 2016, Paleobiological integration of Santacrucian sloths (early Miocene of Patagonia): Ameghiniana, v. 53, p. 100-141.

Toledo, N., Bargo, M.S., and Vizcaíno, S.F., 2015, Muscular reconstruction and functional morphology of the forelimb of early Miocene sloths (Xenarthra, Folivora) of Patagonia: The Anatomical Record, v. 296, p. $305-325$.

Toledo, N., De Iuliis, G., Vizcaíno, S.F., and Bargo, M.S., 2018, The concept of a pedolateral pes revisited: the giant sloths Megatherium and Eremotherium (Xenarthra, Folivora, Megatheriinae) as a case study: Journal of Mammalian Evolution, v. 25, p. 525-537.

Vélez-Juarbe, J., Martin, T., MacPhee, R.D., and Ortega-Ariza, D., 2014, The earliest Caribbean rodents: Oligocene caviomorphs from Puerto Rico: Journal of Vertebrate Paleontology, v. 34, p. 157-163.

White, J. L., 1993, Indicators of locomotor habits in xenarthrans: evidence for locomotor heterogeneity among fossil sloths: Journal of Vertebrate Paleontology, v. 13 , p. $230-242$.

White, J.L., and MacPhee, R.D., 2001, The sloths of the West Indies: a systematic and phylogenetic review, in Woods, C.A., and Sergile, F.E., eds., Biogeography of the West Indies: Patterns and Perspectives: Boca Raton, FL, CRC Press, p. 201-236.

Accepted: 21 October 2021 